\title{
Current state and perspectives of non-electrified railway transport in Poland (part 1)
}

\author{
Stan obecny i perspektywy niezelektryfikowanego transportu \\ kolejowego w Polsce (cz. 1)
}

\begin{abstract}
The article presents the basic information about the current situation related to the basic elements of non-electrified railway transport, which are railway lines and traction vehicles. Data concerning the situation in a highly industrialized country like the USA and in Poland are given. The further part presents the numerical data, location concentration and a map of arrangement of non-electrified lines, as well as general information about diesel vehicles. The next part of the article discusses the ongoing and planned purchases and modernizations of railway diesel vehicles. An important part of the article are data about development plans of the non-electrified railway network in Poland. The last part of the article describes the selected information about costs related to activities for non-electrified railway transport, such as purchases and modernization of rolling stock and networks. The second part of the article will be published in the next issue of quarterly Rail Vehicles.
\end{abstract}

$W$ artykule przedstawiono podstawowe informacje na temat aktualnej sytuacji zwiazanej $z$ podstawowymi elementami niezelektryfikowanego transportu kolejowego, jakimi sa linie kolejowe $i$ pojazdy trakcyjne. Podano dane dotyczqce sytuacji $w$ wysoce uprzemystowionym państwie jakim jest USA $i$ w Polsce. W dalszej części przedstawione została dane liczbowe, koncentracja lokalizacji $i$ mapka rozmieszczenia linii niezelektryfikowanych oraz ogólne informacje o pojazdach spalinowych. W kolejnej czesści artykutu omówione zostaly realizowane i planowane zakupy oraz modernizacje kolejowych pojazdów spalinowych. Istotnq częściq artykulu sq dane o planach rozwoju niezelektryfikowanej sieci kolejowej w Polsce. W ostatniej części artykulu opisano wybrane informacje o kosztach zwiqzanych $z$ działaniami na rzecz niezelektryfikowanego transportu kolejowego, takich jak zakupy i modernizacje taboru i sieci.

Druga część artykułu zostanie opublikowana w kolejnym numerze kwartalnika Pojazdy Szynowe.

\section{Diesel railway against the background of other land transport elements}

The participation of diesel railways in broadly understood land transport is presented, for example, for the USA and Poland, two countries with different histories related to development of industry and construction of railway and its importance for transport.

The transport network of United States is the longest in the world and was shaped in the second half of the 19th century, when the transcontinental lines connecting the Atlantic and Pacific coasts were building. Until the beginning of the 20th century, the length of railway lines increased systematically (in 1916 there were about 430 thousand $\mathrm{km}$ ) and the

\section{Kolej spalinowa na tle innych elementów trans- portu lądowego}

Udział kolei spalinowych w szeroko rozumianym transporcie lądowym przedstawiono przykładowo dla USA i Polski, dwóch państw z różną historią związaną z rozwojem przemysłu i budową kolei i jej znaczenia dla transportu.

Sieć transportowa Stanów Zjednoczonych jest najdłuższa w świecie i została ukształtowana w drugiej połowie XIX w., kiedy budowano linie transkontynentalne łączące wybrzeża Atlantyku i Pacyfiku. Do początków XX w. długość linii kolejowych systematycznie wzrastała (w 1916 r. było ok. 430 tys. km) i kolej była głównym przewoźnikiem towarów (ponad $75 \%$ ładunków) i pasażerów. 
railway was the main carrier of goods (more than $75 \%$ of cargo) and passengers.

The length of railway lines decreased and 219 thousand $\mathrm{km}$ were used in 1992 . Only $1667 \mathrm{~km}$ are the electrified lines, the others are served by diesel locomotives [7].

During the intensified struggle for the quality of the environment, which is also influenced by railway transport, it is important to assess the impact of this branch of the economy on the state of the environment, so it is important information about the organization of transport in the USA, which uses means of diesel transport to a large extent, impacting negatively on the environment than the electrified transport.

The competition of car transport contributed to the liquidation of many unprofitable railway connections.

According to the authors of Solutionary Rail [3] powering the trains with electric energy instead of diesel oil in American conditions has several significant advantages:

- prices of diesel oil are relatively low, but many analysts predict that the increase in these prices will be a long-term trend. However, in the other hand the prices of electric energy are falling with the rapidly growing use of renewable energy sources. It is estimated that even at the current prices, powering the train with electricity is by $50 \%$ cheaper than with diesel oil

- the cost of electric locomotive engines on the global market is by about $20 \%$ lower than that of diesel engines, and maintenance costs are by $25-35 \%$ lower than for Diesel engines

- elimination of diesel locomotives would reduce air pollution, including soot, volatile organic compounds, nitrogen oxides and sulfur oxides, which have an impact on public health and the environment. This is especially important because many railways pass through the urban areas. Moreover, limiting the number of diesel vehicles would also reduce the noise level in cities.

Solutionary Rail points not only to the need to electrify the railways, but also to the use of renewable energy sources to power the new electric railway system.

In the economy of our country, the railway transport of both people and goods is also a significant element of the entire transport system. The share of railway transport in transport in the years 2005-2017 was different in the transport of goods and differently in passenger transport. The share in the transport of goods related to the global transport, calculated in million tons decreased from $17.6 \%$ to $12.0 \%$, while in the transport of persons, calculated in million passengers, these numbers are more favorable, because here there was an increase in the share from $24.8 \%$ to $44.3 \%$. General data on the volume of
Długość linii kolejowych malała i w roku 1992 eksploatowanych było tylko 219 tys. km. Zaledwie 1667 $\mathrm{km}$ stanowią linie zelektryfikowane, pozostałe są obsługiwane przez lokomotywy spalinowe [7].

W czasie wzmożonej walki o jakość środowiska, na którą ma wpływ także transport kolejowy, istotna jest ocena wpływu tej gałęzi gospodarki na stan środowiska, dlatego istotna jest informacja o organizacji transportu w USA, wykorzystującego w znacznym stopniu środki transportu spalinowego, oddziałującego negatywniej na otoczenie niż transport zelektryfikowany.

Konkurencja transportu samochodowego przyczyniła się do likwidacji wielu nierentownych połączeń kolejowych.

Według autorów Solutionary Rail [3] zasilanie pociągów energią elektryczną zamiast olejem napędowym w warunkach amerykańskich ma kilka istotnych zalet:

- ceny oleju napędowego są stosunkowo niskie, ale wielu analityków przewiduje, że długookresowym trendem będzie wzrost tych cen, jednak $z$ drugiej strony ceny energii elektrycznej spadają wraz $\mathrm{z}$ szybko rosnącym wykorzystaniem odnawialnych źródeł energii. Szacuje się, że nawet przy obecnych cenach, zasilanie pociagu energią elektryczną jest o $50 \%$ tańsze niż olejem napędowym

- koszt silników lokomotyw elektrycznych na rynku globalnym jest o około $20 \%$ niższy niż silników spalinowych, a koszty konserwacji są o $25-35 \%$ niższe niż w przypadku silników Diesla

- wyeliminowanie lokomotyw spalinowych zmniejszyłoby zanieczyszczenie powietrza, $w$ tym sadzami, lotnymi związkami organicznymi, tlenkami azotu i tlenkami siarki, które mają wpływ na zdrowie publiczne i środowisko. Jest to szczególnie ważne, ponieważ wiele linii kolejowych przechodzi przez obszary miejskie. Ponadto ograniczenie liczby pojazdów spalinowych zredukowałoby również poziom hałasu w miastach.

Solutionary Rail wskazuje nie tylko na konieczność zelektryfikowania kolei, ale także wykorzystania odnawialnych źródeł energii do zasilania zelektryfikowanego systemu kolei.

W gospodarce naszego kraju transport kolejowy, zarówno osób jak i towarów, także stanowi znaczący element całego systemu transportowego. Udział transportu kolejowego w przewozach w latach 20052017 kształtował się inaczej w transporcie towarów i inaczej $\mathrm{w}$ przewozach osób. Udział $\mathrm{w}$ transporcie towarów odniesiony do transportu globalnego, liczony $\mathrm{w}$ mln ton zmalał z $17,6 \%$ do $12,0 \%$, natomiast $\mathrm{w}$ transporcie osób, liczonym w mln pasażerów, liczby te przedstawiają się korzystniej, bowiem nastapił tutaj wzrost udziału z 24,8\% do 44,3\%. Ogólne dane o wielkościach przewozów i ich zmianach w kolejnych latach przedstawiono w tabl. 1. 
transport and their changes in subsequent years are presented in Table 1 [25].

Udzial transportu kolejowego w przewozach towarów i osób w latach $2005 \div 2017 \quad$ Tabl. 1 The share of railway transport in the transport of goods and persons in the years $2005 \div 2017 \quad$ Table 1

\begin{tabular}{|c|c|c|c|c|c|c|c|}
\hline & 2005 & 2010 & 2013 & 2014 & 2015 & 2016 & 2017 \\
\hline \multicolumn{8}{|l|}{ Przewozy ładunków transportem: } \\
\hline 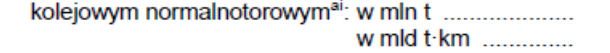 & $\begin{array}{r}233 \\
50,0\end{array}$ & $\begin{array}{r}234 \\
48,8\end{array}$ & $\begin{array}{r}233 \\
50,9\end{array}$ & $\begin{array}{r}228 \\
50,1\end{array}$ & $\begin{array}{r}224 \\
50,6\end{array}$ & $\begin{array}{r}223 \\
50,6\end{array}$ & $\begin{array}{r}240 \\
54,8\end{array}$ \\
\hline samochodowym ${ }^{k}:$ w mln $t$ & 1080 & 1491 & 1553 & 1548 & 1506 & 1547 & 1747 \\
\hline $\mathrm{w}$ mld $\mathrm{t} \cdot \mathrm{km}$ & 120 & 214 & 260 & 263 & 273 & 304 & 349 \\
\hline morskiml: w mln t & 9,4 & 8,4 & 7,0 & 6,8 & 7,0 & 7,2 & 8,3 \\
\hline $\mathrm{w}$ mld t $\cdot \mathrm{km}$ & 31,7 & 19,8 & 16,3 & 13,6 & 12,7 & 8,2 & 9,4 \\
\hline Przewozy pasażerów transportem: & 258 & 261 & 270 & 268 & 277 & 292 & 303 \\
\hline kolejowym normalnotorowymin: w mln pas ...................... & 182 & 179 & 168 & 16,0 & 174 & 19.2 & 20,3 \\
\hline w mld pas $\cdot \mathrm{km} \ldots \ldots \ldots \ldots$ & $\begin{array}{l}18,2 \\
782\end{array}$ & 570 & $\begin{array}{l}10,8 \\
460\end{array}$ & $\begin{array}{l}10,0 \\
432\end{array}$ & 417 & $\begin{array}{l}19,2 \\
390\end{array}$ & $\begin{array}{r}20,3 \\
379\end{array}$ \\
\hline samochodowym ${ }^{\circ}$. w mln pas ......... & 29314 & 21600 & 20039 & 21449 & 21570 & 19168 & 18931 \\
\hline w mln pas $\cdot \mathrm{km}$ & 3994 & 3905 & 3621 & 3711 & 3672 & 3766 & 3739 \\
\hline 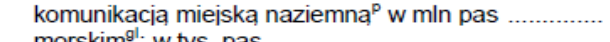 & 1142 & 1189 & 1139 & 1152 & 1262 & 1378 & 1459 \\
\hline morskim $^{g}:$ w tys. pas ........ & 193 & 178 & 156 & 154 & 147 & 151 & 151 \\
\hline
\end{tabular}

Descriptions: przewozy ładunków transportem/ cargo transport, kolejowym normalnotorowym/ by standard gauge railway, samochodowym/ by car, morskim/ by sea, przewozy pasażerów transportem/ passenger transport, kolejowym normalnotorowym/ by standard gauge railway, samochodowym/ by car, komunikacją miejską naziemną/by ground public transport, morskim/ by sea

Data concerning the volume of transport drawn up by the Office of Rail Transport are presented in table 2 and they show the changes in the recent years $[11$, 12].

Wielkości przewozów pasażerów i towarowych $[11,12]$ Tabl. 2 The volume of passenger and freight transport $[11,12]$ Table 2

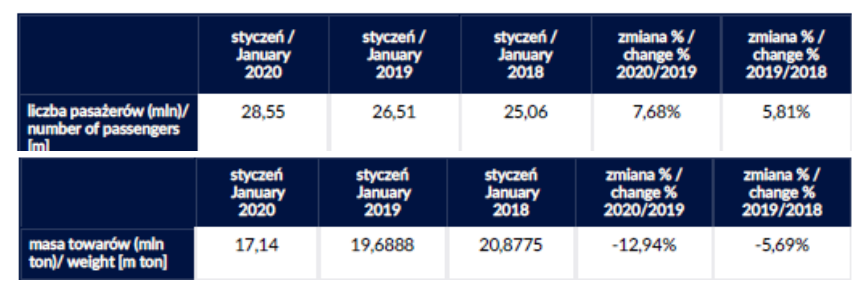

The dominant carriers in the transport of persons and goods in Poland were the companies listed in Table 3, where the percentage share in transports carried out in Poland by these railway companies is presented.

Having in mind the presented in point 3 the number of traction diesel rolling stock in the main companies carrying out transports, it can be found that the majority of transports were carried out on the electrified lines and only some of them took part in the transports carried out by diesel traction vehicles. It can be included to these carriers:

- PKP CARGO with more than 1200 diesel locomotives

- PKP LHS with 77 diesel locomotives

- PKP IC with seven diesel locomotives

- PKP SKM having 10 diesel multiple units in 2019.

2. Characteristics of non-electrified lines in Poland To assess the share of non-electrified lines in the railway transport system in Poland, it is worth to refer this parameter to other European countries. This is presented in the graph in Figure 1. Taking into
Dane dotyczące wielkości przewozów, zestawione przez Urząd Transportu Kolejowego, przedstawiono w tabl. 2 i przedstawiają one zmiany w ostatnich latach.

Dominującymi przewoźnikami w transporcie osób i towarów w Polsce były spółki wymienione w tabl. 3, w której zestawiono procentowy udział w przewozach realizowanych w Polsce przez te spółki kolejowe.

Udzial spólek kolejowych w przewozach Tabl. 3 Share of the railway companies in transports Table 3

\begin{tabular}{|l|c|c|c|}
\hline & $\mathbf{1 2 0 2 0}$ & $\mathbf{1 2 0 1 9}$ & $\mathbf{2 0 1 9}$ \\
\hline PKP Intercity & $49,82 \%$ & $48,27 \%$ & $52,78 \%$ \\
\hline Polregio & $21,39 \%$ & $21,90 \%$ & $20,21 \%$ \\
\hline Koleje Mazowieckie & $9,81 \%$ & $10,66 \%$ & $9,70 \%$ \\
\hline PKP SKM & $4,63 \%$ & $4,86 \%$ & $4,49 \%$ \\
\hline Koleje Dolnoslaskie & $3,34 \%$ & $3,31 \%$ & $3,09 \%$ \\
\hline Koleje Slaskie & $3,33 \%$ & $3,90 \%$ & $3,27 \%$ \\
\hline Koleje Wielkopolskie & $2,25 \%$ & $2,26 \%$ & $1,99 \%$ \\
\hline SKM Warszawa & $1,77 \%$ & $1,68 \%$ & $1,50 \%$ \\
\hline PKP Cargo & $37,70 \%$ & $42,64 \%$ & $40,35 \%$ \\
\hline DB Cargo Polska & $18,19 \%$ & $18,21 \%$ & $16,91 \%$ \\
\hline Lotos Kolej & $5,34 \%$ & $4,68 \%$ & $5,42 \%$ \\
\hline PUK Kolprem & $4,19 \%$ & $3,29 \%$ & $3,32 \%$ \\
\hline CTL Logistics & $3,86 \%$ & $3,42 \%$ & $3,55 \%$ \\
\hline PKP LHS & $3,80 \%$ & $4,74 \%$ & $4,13 \%$ \\
\hline Orlen Kot-Trans & $3,11 \%$ & $2,42 \%$ & $2,55 \%$ \\
\hline
\end{tabular}

Mając na uwadze przedstawiony w pkt. 3 stan liczbowy trakcyjnego taboru spalinowego w głównych spółkach realizujących przewozy można stwierdzić, że większość przewozów wykonywana była na liniach zelektryfikowanych i tylko niektóre $\mathrm{z}$ nich miały udział $\mathrm{w}$ przewozach realizowanych spalinowymi pojazdami trakcyjnymi. Do tych przewoźników można zaliczyć:

- PKP CARGO z ponad 1200 lokomotywami spalinowymi

- PKP LHS z 77 lokomotywami spalinowymi 
account the average value in the European Union (54\%), Poland with $64 \%$ is at the top of this list. It also means that according to Allianz pro Schiene, the non-electrified lines are $36 \%$ of the railway network in Poland.

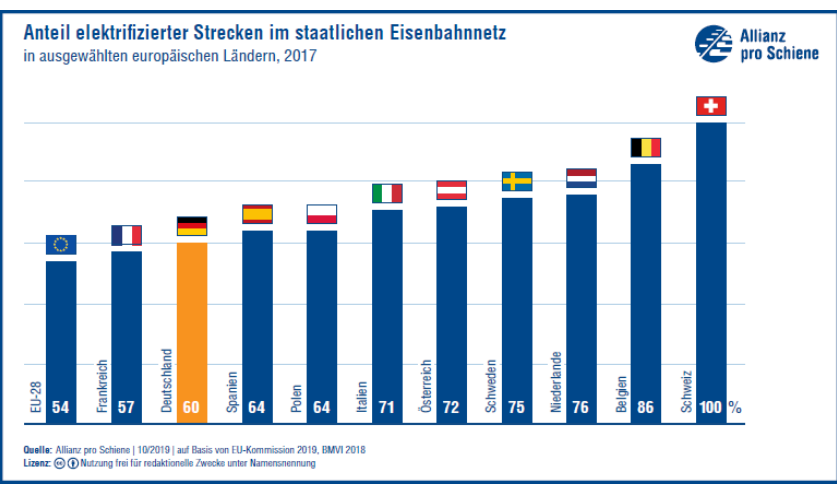

Rys. 1. Procentowy udział linii zelektryfikowanych w krajach europejskich [13]

Fig. 1. Percentage share of electrified lines in European countries [13]

Table 4 presents the numbers showing the changes concerning the length of railway lines in Poland, including the non-electrified lines.
- PKP IC z siedmioma lokomotywami spalinowymi - PKP SKM dysponującą w 2019 r. 10 spalinowymi zespołami trakcyjnymi.

\section{Charakterystyka linii niezelektryfikowanych $w$ Polsce}

Dla oceny udziału linii niezelektryfikowanych w systemie transportu kolejowego w Polsce warto odnieść ten parametr do innych krajów europejskich. Przedstawia to wykres na rys. 1. Biorąc pod uwage wartość średnią w Unii Europejskiej (54\%), Polska z 64\% znajduje się w czołówce tej listy. Oznacza to także, że według danych Allianz pro Schiene w Polsce 36\% sieci kolejowej stanowią linie niezelektryfikowane.

W tablicy 4 zestawiono liczby przedstawiające zmiany dotyczące długości linii kolejowych w Polsce, w tym także linii niezelektryfikowanych.

Linie kolejowe w Polsce w zdecydowanej większości zarządzane są przez PKP Polskie Linie Kolejowe S.A. Długość linii kolejowych zarządzanych przez tę spółkę, wg stanu na 31 grudnia 2018 roku wynosiła $18.536 \mathrm{~km}$, w tym linii zelektryfikowanych było $11.862 \mathrm{~km}$, co stanowi $64 \%$, zatem potwierdza to dane Allianz pro Schiene. Dane te zestawiono w tabl. 5. W stosunku do roku poprzedniego stan ten pozostal praktycznie bez zmiany.

Zmiana długości linii kolejowych w Polsce w latach 2005 $\div 2017$ Tabl. 4

Change of the length of railway lines in Poland in 2005-2017

Table 4

\begin{tabular}{|c|c|c|c|c|c|c|c|}
\hline & 2005 & 2010 & 2013 & 2014 & 2015 & 2016 & 2017 \\
\hline $\begin{array}{l}\text { Linie kolejowe eksploatowane normalnotorowe }{ }^{\text {ab }} \text { (stan } \\
\text { w dniu } 31 \text { XII): } \\
\text { w tysiacach kilometrów }\end{array}$ & & & & & & & \\
\hline na $100 \mathrm{~km}^{2}$ powierzchni ogólnej $w \mathrm{~km}$ & 19,8 & 20,1 & 19,3 & 19,2 & 19,2 & 19,1 & 19,2 \\
\hline w tvm zelektrvfikowane: $\mathrm{w}$ tvs. $\mathrm{km}$ & $\begin{array}{r}6,3 \\
11,9\end{array}$ & $\begin{array}{r}6,4 \\
11,9\end{array}$ & $\begin{array}{r}6,2 \\
11,9\end{array}$ & $\begin{array}{r}6,2 \\
11,8\end{array}$ & $\begin{array}{r}6,2 \\
11,9\end{array}$ & $\begin{array}{r}6,1 \\
119\end{array}$ & $\begin{array}{r}6,1 \\
119\end{array}$ \\
\hline
\end{tabular}

Descriptions: linie kolejowe eksploatowane normalnotorowe (stan w dniu $31 \mathrm{XII}$ )/ operated standard gauge railway lines ( as of 31 December), w tysiącach kilometrów/ in thousands of kilometers, na $100 \mathrm{~km}$ powierzchni ogólnej w km/ on $100 \mathrm{~km}$ of total area in $\mathrm{km}$, w tym zelektryfikowane w tys. $\mathrm{km} /$ including electrified in thousand $\mathrm{km}$.

\section{Długość linii kolejowych w Polsce zarządzanych przez PKP PLK Length of railway lines in Poland managed by PKP PLK \\ Tabl. 5 \\ Table 5}

Urządzenia elektroenergetyczne zarządzane przez PKP Polskie Linie Kolejowe S.A. w 2018 roku
w porównaniu do 2017 roku
\begin{tabular}{|l|c|c|c|}
\hline \multicolumn{1}{|c|}{ Wyszczególnienie } & j.m. & 2018 & 2017 \\
\hline & & & \\
\hline Urządzenia sieci trakcyjnej: & & 11862 & 11816 \\
\hline đługość linii kolejowych zelektryfikowanych & $\mathrm{km}$ & 24783 & 24697 \\
\hline długość sieci trakcyjnej & tkm & lata \\
\hline
\end{tabular}

Descriptions: Urządzenia elektroenergetyczne zarządzane przez PKP Polskie Linie Kolejowe S.A w 2018 roku w porównaniu do 2017 roku /electric power devices managed by PKP Polskie Linie Kolejowe S.A. in 2018 compared to 2017, wyszczególnienie/ specification, lata/years, urządzenia sieci trakcyjnej/ devices of traction network, długość linii kolejowych zelektryfikowanych/ length of electrified railway lines, długość sieci trakcyjnej/ length of traction network

The arrangement of non-electrified lines across the country is unequal and their main concentration takes place in the western provinces, where there are also most of the railway lines, which is confirmed by the map in Fig. 2.
Rozmieszczenie linii niezelektryfikowanych na obszarze kraju jest nierównomierne $\mathrm{i}$ ich główna koncentracja ma miejsce w województwach zachodnich, gdzie znajduje się także większość linii kolejowych, co potwierdza mapka na rys. 2. 


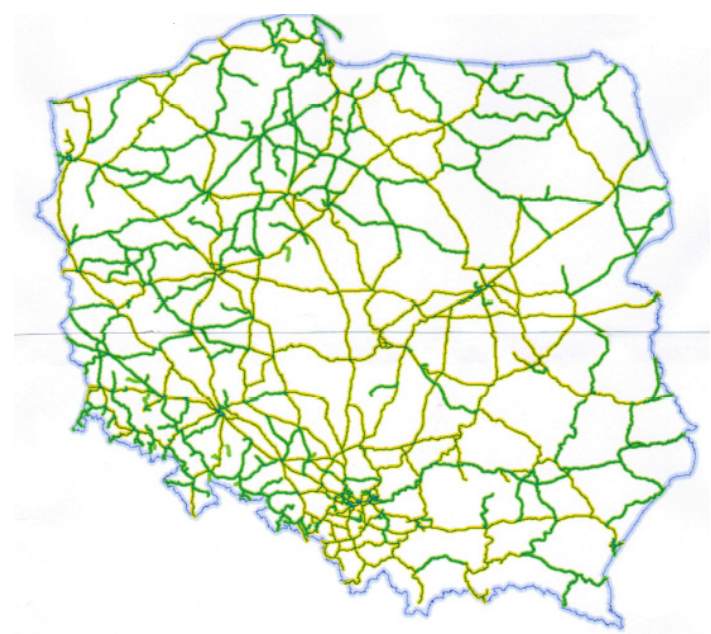

Rys. 2. Rozmieszczenie linii kolejowych w Polsce [4] (kolor żółty - linie zelektryfikowane, kolor zielony - linie niezelektryfikwane)

Fig 2. Arrangement of railway lines in Poland [4] (yellow colour - electrified lines, green colour- non-electrified lines)

From the presented map it appears that the densest railway network is in the north-western, western and south-western part of the country, but there is also the highest percentage of non-electrified lines there.

For example, according to the available data in the Podkarpackie Province, the length of railway operated lines is as follows [27]:

- in 2011 a total of $1024 \mathrm{~km}$, including $355 \mathrm{~km}$ of electrified ones

- in 2020 (estimated) a total $1029 \mathrm{~km}$, including $436 \mathrm{~km}$ of electrified ones.

The second province which provided data on the length of railway lines is Warmińsko - Mazurskie Province. The network in this province was $1326 \mathrm{~km}$ in 2003 and only $23 \%$ were two - and more track lines, and $37 \%$ of lines were electrified [26].

\section{Types, number and age of rail diesel vehicles at the disposal of carriers}

The straight majority of diesel traction rolling stock is at the disposal of a few key carriers. These include, among others: PKP CARGO, PKP InterCity, PKP Broad Gauge Metallurgical Railway (PKP LHS), PKP Fast Urban Railway in Tri-city (PKP SKM). According to the Annual Report of PKP Group for 2018 the number of traction rolling stock, including diesel rolling stock, was as follows [23]:

- PKP CARGO Group owned 2352 locomotives, including 1286 diesel locomotives (as of 31 December 2018)

- PKP IC had 363 locomotives (including seven diesel locomotives rented from ČD railway), 74 electric multiple units (20 units of ED250, 20 units of ED160, 20 units of ED161 and 14 units of ED74), and 2114 passenger wagons (as of 31 December 2018)

- PKP LHS owned 77 diesel locomotives (at the end of 2018)
Z przedstawionej mapy wynika, że najgętsza sieć linii kolejowych jest zlokalizowana w północnozachodniej, zachodniej i południowozachodniej części kraju, z tym że tam także jest procentowo najwięcej linii niezelektryfikowanych.

Przykładowo, wg dostępnych danych w woj. podkarpackim długości eksploatowanych linii kolejowych są następujące [27]:

- w 2011 r. ogółem 1024 km, w tym zelektryfikowanych $355 \mathrm{~km}$

- w 2020 r. (szacunkowo) ogółem 1029 km, w tym zelektryfikowanych $436 \mathrm{~km}$.

Drugim województwem, które udostępniło dane o długości linii kolejowych, jest województwo Warmińsko - Mazurskie. Sieć w tym województwie liczyła w 2003 r. $1326 \mathrm{~km}$ i tylko 23\% stanowily linie dwu - i więcej torowe, a zelektryfikowanych było $37 \%$ linii [26].

3. Typy, stan liczbowy i wiek szynowych pojazdów spalinowych w dyspozycji przewoźników

Zdecydowana większość trakcyjnego taboru spalinowego jest w dyspozycji kilku kluczowych przewoźników. Należą do nich m.in.: PKP CARGO, PKP InterCity, PKP Linia Hutnicza Szerokotorowa, PKP Szybka Kolej Miejska w Trójmieście. Według Raportu Rocznego Grupy PKP za 2018 stan liczbowy taboru trakcyjnego, w tym spalinowego, był następujący [23]:

- Grupa PKP CARGO posiadała 2.352 lokomotywy, w tym 1.286 lokomotyw spalinowych (stan na 31 grudnia 2018 r.)

- Spółka PKP IC posiadała 363 lokomotywy (w tym siedem lokomotyw spalinowych wynajętych od kolei ČD), 74 elektryczne zespoły trakcyjne (20 szt. ED250, 20 szt. ED160, 20 szt. ED161 oraz 14 szt. ED74) i 2.114 wagonów pasażerskich (stan na 31 grudnia 2018 r.)

- Spółka PKP LHS posiadała 77 lokomotyw spalinowych (stan na koniec 2018 r.)

- PKP SKM w 2018 roku miała na stanie 13 spalinowych zespołów trakcyjnych, jednak od 9 grudnia 2018 roku ich liczba została ograniczona do 10 szt.

Lista typów i ilości s.z.t. w dyspozycji głównych przewoźników ujętych w tabl. 3 (dane za 2019 r.) jest przedstawiona $\mathrm{w}$ poniższej tabl. 6 , a podobna lista dotyczaca lokomotyw spalinowych będących w dyspozycji przewoźników ujętych $\mathrm{w}$ tabl. 3, w tabl. 7 . Łącznie przewoźnicy dysponowali 244 spalinowymi zespołami trakcyjnymi $[9,10]$.

Według GUS pod koniec 2019 r. w Polsce było 2.149 czynnych lokomotyw spalinowych [25], a łącznie wyprodukowano ich 4.152 szt. [9].

Przykładowo, wg danych PKP LHS, średni wiek spalinowych lokomotyw liniowych wynosił 39 lat, natomiast manewrowych 42 lata. Także średni wiek spalinowych lokomotyw używanych przez pasażerskich 
- PKP SKM: in 2018 it had 13 diesel multiple units, but since 9 December 2018 their number has been limited to 10 units.

List of types and quantities of diesel multiple units at the disposal of the main carriers given in table 3 (data for 2019) is presented in table 6, and a similar list concerning the diesel locomotives at the disposal of carriers included in table 3 is in the table 7 below. In total, the carriers had 244 diesel multiple units $[9,10]$. operatorów w Polsce rośnie i na koniec 2018 roku wynosił 41,7 lat [18].

Warto podkreślić, że zarówno w przypadku lokomotyw spalinowych jak i elektrycznych, zakres planowanych inwestycji nie będzie miał dużego znaczenia dla średniego wieku taboru [38].

Lista spalinowych zespołów trakcyjnych w posiadaniu przewoźników w Polsce

Tabl. 6

List of diesel multiple units in possession of carriers in Poland

\begin{tabular}{|c|c|c|c|c|c|c|c|c|c|c|c|c|c|c|}
\hline $\begin{array}{l}\text { Lp./ } \\
\text { Item }\end{array}$ & $\begin{array}{l}\text { Przewoźnik/Typ s.z.t./ } \\
\text { Carrier/Type of diesel } \\
\text { multiple units }\end{array}$ & SA101 & SA102 & SA103 & SA105 & SA106 & SA107 & SA108 & SA109 & SA123 & SA130 & SA131 & SA132 & SA133 \\
\hline 1 & Przewozy Regionalne & 1 & 2 & 13 & 6 & 5 & 2 & 6 & 7 & & & 1 & 3 & 24 \\
\hline 2 & Koleje Mazowieckie & & & & & & & & & & & & & \\
\hline 3 & PKP Intercity & & & & & & & & & & & & & \\
\hline 4 & PKP SKM & & & & & & & & & & & & & 3 \\
\hline 5 & SKM Warszawa & & & & & & & & & & & & & \\
\hline 6 & Koleje Śląskie & & & & & & & & & & & & & \\
\hline 7 & Koleje Dolnośląskie & & & & & 1 & & & 2 & & & & 1 & \\
\hline 8 & Koleje Wielkopolskie & & & & & & & 4 & & & & & 11 & \\
\hline
\end{tabular}

(cd)/Table 6 (cont.)
\begin{tabular}{|l|l|l|l|l|l|l|l|l|l|l|l|l|l|l|l|}
\hline $\begin{array}{l}\text { Lp// } \\
\text { Item }\end{array}$ & $\begin{array}{l}\text { Przenónik/Typs.zt. } \\
\text { Carrier/Type of diesel } \\
\text { multipleunits }\end{array}$ & $\begin{array}{l}\text { SA13 } \\
4\end{array}$ & $\begin{array}{l}\text { SA13 } \\
5\end{array}$ & $\begin{array}{l}\text { SA13 } \\
6\end{array}$ & $\begin{array}{l}\text { SA13 } \\
7\end{array}$ & $\begin{array}{l}\text { SA13 } \\
8\end{array}$ & $\begin{array}{l}\text { SA13 } \\
9\end{array}$ & $\begin{array}{l}\text { SA14 } \\
0\end{array}$ & $\begin{array}{l}\text { VI6 } \\
27\end{array}$ & $\begin{array}{l}\text { VT6 } \\
28\end{array}$ & $\begin{array}{l}\text { VT6 } \\
46\end{array}$ & $\begin{array}{l}401 \mathrm{D} \\
\text { a }\end{array}$ & $\begin{array}{l}409 \mathrm{D} \\
\text { a }\end{array}$ & $\begin{array}{l}\text { MR/ } \\
\text { MRD }\end{array}$ & Y \\
\hline 1 & Przenozy Regionalne & 17 & 8 & 12 & 7 & 3 & 11 & 2 & & & & & & & \\
\hline 2 & KolejeMrzowieckie & & 7 & & & & & & 4 & 2 & & & & & \\
\hline 3 & PKP Intercity & & & & & & & 2 & & & & & & & \\
\hline 4 & PKPSKM & & & 7 & 2 & 1 & & & & & & & & & \\
\hline 5 & SKMWarszana & & & & & & & & & & & & & & \\
\hline 6 & KolejeŚląkie & & & & & 1 & & & & & & & & & \\
\hline 7 & KolejeDolnoślaskie & 8 & 9 & & & & 4 & & & & & & & & \\
\hline 8 & Koleje Wielkopolskie & 2 & & & & & 4 & & & & & & & & \\
\hline
\end{tabular}

Lista lokomotyw spalinowych w posiadaniu przewoźników w Polsce List of diesel locomotives in possession of carriers in Poland

Tabl. 7

Table 7

\begin{tabular}{|l|l|l|l|l|l|l|l|l|l|l|l|l|l|}
\hline Lp./Item & $\begin{array}{l}\text { Carrier/ Type of } \\
\text { locomotive }\end{array}$ & SM03 & SM04 & SM30 & SM31 & SM32 & SM42 & SM48 & SU42 & SU45 & SU46 & SU160 & T448 \\
\hline 1 & PKP Cargo & $*$ & & $*$ & $*$ & $*$ & & $*$ & & $*$ \\
\hline 2 & DB Cargo & & & & 1 & & 5 & & & \\
\hline 3 & Lotos Kolej & & & & & & $*$ & & & \\
\hline 4 & PKP LHS & & & 1 & & 1 & & 7 & & \\
\hline 5 & $\begin{array}{l}\text { CTL Logis- } \\
\text { tics/Train }\end{array}$ & & & & & & 5 & & \\
\hline 6 & PUK Kolprem & & & & & & $*$ & $*$ & & \\
\hline 7 & Orlen Kol - Trans & & & & & & $*$ & & & \\
\hline
\end{tabular}

Tabl. 7 (cd)/ Table 7 (cont.)

\begin{tabular}{|l|l|l|l|l|l|l|l|l|l|l|l|l|}
\hline Lp./Item & $\begin{array}{l}\text { Carrier/ Type of } \\
\text { locomotive }\end{array}$ & S200 & ST40 & ST43 & ST44 & ST45 & ST46 & $\begin{array}{l}\text { ST48 } \\
1)\end{array}$ & BR232 & Ls1000 & $\begin{array}{l}\text { Class 66 } \\
2\end{array}$ & MakDE \\
\hline 1 & PKPCargo & & & $*$ & $*$ & $*$ & $*$ & $*$ & & & & \\
\hline 2 & DBCargo & & 12 & & 4 & & & & 10 & 1 & 15 & 7 \\
\hline 3 & Lotos Kolej & & & & & & & & & & & \\
\hline 4 & PKPLHS & & & & 61 & & & 7 & & & & \\
\hline 5 & $\begin{array}{l}\text { CTLLogis- } \\
\text { tics/Train }\end{array}$ & $*$ & & & 2 & & & & & & & \\
\hline 6 & PUKKolprem & $*$ & & & $*$ & & & & & & & \\
\hline 7 & Oten Kol-Trans & & & & $*$ & & & & $*$ & & & \\
\hline
\end{tabular}

* brak danych liczbowych/no numerical data 1) także jako $15 \mathrm{D} /$ also as $15 \mathrm{D}$ 2) modernizacja SM42/ modernization of SM42 
According to the Central Statistical Office, at the end of 2019 there were 2149 active diesel locomotives in Poland [25], and 4142 units were produced in total[9].

For example, according to PKP LHS data, the average age of diesel line locomotives was 39 years, whereas for the shunting ones was 42 years. Also, the average age of diesel locomotives used by passenger operators in Poland was growing and at the end of 2018 was 41.7 years [18].

It is worth to emphasize that in the case of both diesel and electric locomotives, the scope of planned investments will not have a significant importance for the average age of rolling stock [38].

4. Completed and planned purchases and modernizations of railway diesel vehicles

4.1. Activities of railway carriers

a) One of the largest operators operating on PKP PLK S.A. tracks is the PKP Cargo S.A. company having a large number of locomotives in its rolling stock, including diesel ones. Table 6 below presents the change of the numerical state of this carrier's locomotives in recent years.
4. Zrealizowane i planowane zakupy oraz modernizacje kolejowych pojazdów spalinowych

4.1. Dziatania przewoźników kolejowych

a) Jednym z największych operatorów działających na torach PKP PLK S.A. jest firma PKP Cargo S.A. posiadająca $\mathrm{w}$ swoim parku taborowym duża liczbę lokomotyw, w tym także spalinowych. W tablicy 8 poniżej zestawiono zmianę stanu liczbowego lokomotyw tego przewoźnika w ostatnich latach.

Spółka podpisała umowę z konsorcjum firm NEWAG S.A. oraz NEWAG LEASE Sp. $z$ o.o. na zakup 31 nowych sześcioosiowych lokomotyw elektrycznych, przy czym harmonogram umowy zakładał dostawę w IV kw. 2019 r. 7 lokomotyw wyposażonych $\mathrm{w}$ tzw. spalinowy moduł dojazdowy.

PKP CARGO S.A. bierze udział z PESA Bydgoszcz S.A. i z Łukasiewicz - Instytutem Pojazdów Szynowych „TABOR” w Poznaniu w pracach badawczo - rozwojowych przy budowie dwusystemowej lokomotywy autonomicznej. Po dwóch etapach wstępnych:

Stan liczbowy lokomotyw PKP Cargo S.A. Tabl. 6 [21]

Numerical state of PKP Cargo S.A. locomotives Table 6 [21]

\begin{tabular}{|c|c|c|c|c|c|c|c|}
\hline Wyszczególnienie & $31 / 12 / 2019$ & $31 / 12 / 2018$ & $31 / 12 / 2017$ & $31 / 12 / 2016$ & $31 / 12 / 2015$ & $31 / 12 / 2014$ & $\begin{array}{c}\text { Zmiana } \\
\text { 2019-2018 }\end{array}$ \\
\hline lokomotywy spalinowe & 1261 & 1286 & 1272 & 1398 & 1429 & 1300 & -25 \\
\hline w tym PKP CARGO S.A. & 1065 & 1077 & 1076 & 1200 & 1231 & 1256 & -12 \\
\hline lokomotywy elektryczne & 1079 & 1066 & 1062 & 1173 & 1173 & 1162 & 13 \\
\hline w tym PKP CARGO S.A. & 1059 & 1049 & 1048 & 1161 & 1158 & 1162 & 10 \\
\hline Razem & 2340 & 2352 & 2334 & 2571 & 2602 & 2462 & -12 \\
\hline w tym PKP CARGO S.A. & 2124 & 2126 & 2124 & 2361 & 2389 & 2418 & -2 \\
\hline
\end{tabular}

The company signed an contract with a consortium of NEWAG S.A. and NEWAG LEASE Sp. z o.o. companies for the purchase of 31 new six-axle electric locomotives, with the schedule of contract assumed the delivery of seven locomotives equipped with the so-called diesel access module in the fourth quarter of 2019.

PKP CARGO S.A. participates with PESA Bydgoszcz S.A. and Łukasiewicz - Instytut Pojazdów Szynowych "TABOR" in Poznań in research and development works on the construction of a twosystem autonomous locomotive. After two preliminary stages:

- development of technical assumptions and locomotive configuration and their verification by scientists of Łukasiewicz - IPS „TABOR”

- carrying out design and research works.

PESA will start the construction of a two-system, electric - diesel autonomous locomotive. The first vehicle will be tested by PKP CARGO.

The PKP CARGO S.A. company also executes the
- opracowanie założeń technicznych i konfiguracji lokomotywy i ich weryfikacji przez naukowców z IPS „TABOR”

- realizacja prac projektowych i badawczych, PESA przystapi do budowy dwusystemowej, elektryczno - spalinowej lokomotywy autonomicznej. Pierwszy pojazd będzie testowany przez PKP CARGO.

Spółka PKP CARGO S.A. realizuje też umowę, na podstawie której NEWAG Group S.A. w latach 2018? 2021 wykona naprawy główne poziomu P5 połączone z modernizacją 60 lokomotyw spalinowych serii SM48. Seria SM48 zmieniona zostanie na typ ST48, czyli zmieni się przeznaczenie lokomotyw z manewrowych na liniowe. W 2019 r. wykonano 20 takich modernizacji.

$\mathrm{W}$ trakcie realizacji jest także umowa, na podstawie której w latach w latach 2019? 2020 PESA Bydgoszcz S.A. wykonana naprawy poziomu P5 połączone z modernizacją 38 lokomotyw spalinowych serii ST44. W 2019 r. wykonano 9 takich modernizacji. 
contract under which NEWAG Group S.A. in 20182021 will perform the main repairs of the P5 level combined with the modernization of 60 diesel locomotives of SM48 series. The SM48 series will be changed to the ST48 type that the use of locomotives will be changed from shunting to line. 20 such modernizations were carried out in 2019.

A contract is also being implemented, based on which, in the years 2019-2020 PESA Bydgoszcz S.A. carries out the repairs of P5 level combined with modernization of 38 diesel locomotives of ST44 series. Nine (9) such modernizations were made in 2019.

b) In July 2017 the contract was signed between PKP LHS and NEWAG S.A. for the modernization of ten (10) ST44 diesel locomotives with a change to type $311 \mathrm{Da}$. The original schedule assumed the delivery of one unit (1) per month [17].

c) On 25 September 2013 NEWAG S.A. signed a contract with PKP Intercity for the modernization of 20 diesel locomotives of type SM42. The modernization will increase the power of the locomotives to the level of $800-1000 \mathrm{~kW}$, and the maximum speed to $90 \mathrm{~km} / \mathrm{h}$. Apart from replacing the diesel engine with a new type, the vehicles will be equipped with devices to supply trainsets with electric energy. The modernized rolling stock will have declarations of compliance with the applicable environmental, safety and TSI (technical interoperability specifications) and Directive 2004/26 specifying the requirements for pollution emitted by diesel engines of railway vehicles [16].

d) In 2019 PKP Intercity chose H. Cegielski Fabryka Pojazdów Szynowych in Poznań as the contractor of modernization of thirteen (13) SM42 diesel shunting locomotives.

Locomotives of the SM42 series will be modernized to two-aggregate ones with the function of supplying wagons with electric energy. The locomotives will gain the modern diesel engines that meet the Stage IIIB standard of exhaust gas emission. New solutions will be introduced, including microprocessor control that will improve the safety of locomotives and reduce the fuel consumption. Noise and vibrations, both emitted to the environment and those negatively affecting the personnel operating the locomotive and passengers, will be reduced.

The modernized locomotives will be used especially for shunting work. Moreover, they will be able to be used to service the temporarily closed parts of the routes due to the modernization of railway lines, to service the trains in emergency situations related to traction damage, and seasonally started trains riding on the non-electrified routes [19].

4.2. Activities taken by producers

Polish producers have the various types of railway vehicles in their production package, including diesel b) W lipcu 2017 roku pomiędzy PKP Linia Hutnicza Szerokotorowa Spółka z o.o. a NEWAG S.A. została podpisana umowa na modernizację 10 lokomotyw spalinowych ST44 ze zmianą na typ 311Da. Pierwotny harmonogram zakładał dostawe jednej sztuki miesięcznie [17].

c) NEWAG S.A. podpisał 25 września 2013 r. umowę z PKP Intercity na modernizację 20 lokomotyw spalinowych typu SM42. Modernizacja zwiększy moc lokomotyw do poziomu 800 ? $1000 \mathrm{~kW}$, a maksymalną prędkość do $90 \mathrm{~km} / \mathrm{h}$. W pojazdach, oprócz wymiany silnika spalinowego na nowy typ, będą zainstalowane urządzenia umożliwiające zasilenie składów pociagó́w w energię elektryczną. Zmodernizowany tabor będzie posiadał deklaracje zgodności z obowiązującymi normami środowiskowymi, bezpieczeństwa i TSI (Technicznymi Specyfikacjami Interoperacyjności) oraz Dyrektywą 2004/26 określającą wymagania w zakresie zanieczyszczeń emitowanych przez silniki spalinowe pojazdów kolejowych [16].

d) PKP Intercity w 2019 r. wybrało H. Cegielski Fabrykę Pojazdów Szynowych w Poznaniu na wykonawcę modernizacji 13 spalinowych lokomotyw manewrowych SM42.

Lokomotywy te zostaną zmodernizowane na dwuagregatowe $\mathrm{z}$ funkcją zasilania wagonów $\mathrm{w}$ energię elektryczną. Lokomotywy zyskają nowoczesne silniki spalinowe spełniające normę emisji spalin na poziomie Stage IIIB. Wprowadzone będą nowe rozwiązania, m.in. mikroprocesorowe sterowanie mające poprawić bezpieczeństwo pracy lokomotyw i zmniejszyć zużycie paliwa. Obniżony zostanie hałas i drgania, zarówno emitowane do otoczenia, jak i te negatywnie wpływające na personel obsługujący lokomotywę.

Zmodernizowane lokomotywy będą wykorzystywane przede wszystkim do pracy manewrowej. Ponadto będą mogły być wykorzystywane do obsługi części szlaków czasowo zamykanych z uwagi na modernizacje linii kolejowych, do obsługi pociągów w awaryjnych sytuacjach związanych z uszkodzeniami trakcji oraz sezonowo uruchamianych składów, prowadzonych po niezelektryfikowanych szlakach [19].

\subsection{Działania podjęte przez producentów}

Polscy producenci w swoim pakiecie produkcyjnym mają różnego rodzaju pojazdy kolejowe, w tym także spalinowe. Przykładowo H. Cegielski - Fabryka Pojazdów Szynowych oferuje zespoły trakcyjne $\mathrm{z}$ różnego rodzaju napędem:

- dwunapędowe elektryczno - spalinowe

- elektryczne

- spalinowe [8].

Fabryka pojazdów szynowych NEWAG S.A. także wykonuje kompletną modernizację lokomotyw spalinowych SM42 i SM48 jako typy 18I, 6Dl, 6Dg, 
ones. For example, H. Cegielski - Fabryka Pojazdów Szynowych offers multiple units with their own drive:

- two-drive electric-diesel

- electric

- diesel [8].

NEWAG S.A. rail vehicle factory also performs the complete modernization of SM42 and SM48 diesel locomotives as types SM42 and SM48 as types 18I, $6 \mathrm{D} 1,6 \mathrm{Dg}, 15 / 16 \mathrm{D}$ and diesel multiple units. Figures 3 and 4 present the examples of such modernized vehicles $[14,15]$.

The process of modernization of the locomotives presented above includes the construction of a completely new body, the use of new engines and power generators. The cabs are equipped with the modern control systems and a digital monitoring system. Cameras mounted on the front and in the driver's cab increase the view of the trail and significantly make maneuvering work easier.

Modernization of the diesel multiple units provides high driving dynamics, speed up to $120 \mathrm{~km} / \mathrm{h}$ and low fuel consumption. The modernized units offer a functional and modern interior of the passenger compartment equipped with air conditioners and comfortable seats. Advanced drive technology, vehicle suspension and soundproofing the passenger compartment will give a high level of travel comfort. Modernizations are also a significant part of the production of another key Polish producer of rail vehicles, which is PESA Bydgoszcz. The drive systems, that are modernized there, are mainly subject to modernization, which results are:

- extended engine life

- reduction of maintenance costs by about $50 \%$

- savings of fuel consumption by 15 - $25 \%$

- double reduction of engine oil consumption

- increased mileages between repairs

- improvement of vehicle reliability and driver's working conditions

- increasing the power of the locomotive by up to $50 \%$.

Modern, economical diesel engines and generators of leading world producers are used. In order to improve the aesthetics and comfort of work, driver's cabs are subject to a thorough reconstruction.

The first locomotive modernized by PESA in accordance with this idea is the SM42 in twoaggregate version. Two-aggregate drive eliminates disproportionate high fuel consumption, which is a typical problem of classic shunting locomotives.

Application of two-aggregate in the modernized locomotives brings a number of benefits:

- diesel engine operation with higher efficiency gives lower fuel consumption

- visibility from the driver's cab is improved as a result of the lowering of the machine rooms when installing the diesel engines of smaller dimensions
15/16D oraz spalinowych zespołów trakcyjnych. Na rysunkach 3 i 4 przedstawiono przykłady takich zmodernizowanych pojazdów $[14,15]$.
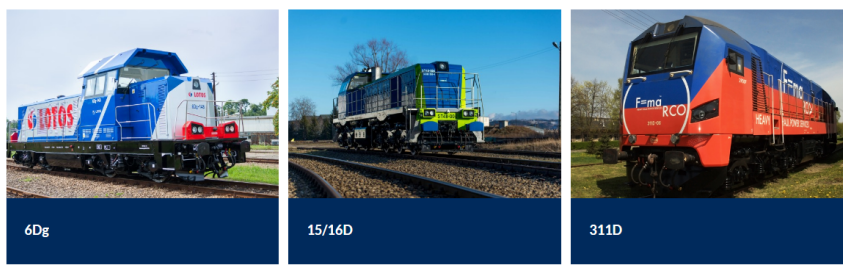

Rys. 3. Przykłady modernizowanych lokomotyw spalinowych Fig. 3. Examples of modernized diesel locomotives
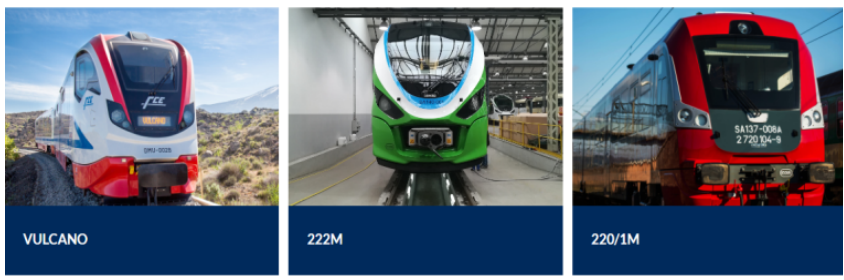

Rys. 4. Przykłady modernizowanych s.z.t.

Fig. 4. Examples of modernized diesel multiple units.

Proces modernizacji wyżej pokazanych lokomotyw obejmuje budowę całkowicie nowego nadwozia, zastosowanie nowych silników i agregatów prądotwórczych. Kabiny wyposażone zostają w nowoczesne systemy sterowania i cyfrowy system monitoringu. Kamery zamontowane na czołach oraz w kabinie maszynisty zwiększają pole widzenia szlaku i znacznie ułatwiaja prace manewrowe.

Modernizacja s.z.t. zapewni lepszą dynamikę jazdy, prędkość do $120 \mathrm{~km} / \mathrm{h}$ oraz niskie zużycia paliwa. Zmodernizowane zespoły oferują funkcjonalny i nowoczesny wystrój przedziału pasażerskiego wyposażonego w klimatyzatory i wygodne fotele. Zaawansowana technologia napędu, zawieszenia pojazdu oraz wyciszenie kabiny pasażerskiej da wysoki komfort podróży.

Modernizacje są także znaczącą częścią produkcji kolejnego kluczowego polskiego producenta pojazdów szynowych, jakim jest PESA Bydgoszcz. Wykonywanym tam modernizacjom podlegają głównie układy napędowe, czego efektem jest:

- wydłużenie żywotności silnika

- obniżenie kosztów utrzymania o ok. 50\%

- oszczędność w zużyciu paliwa o 15 - 25\%

- dwukrotne obniżenie zużycia oleju silnikowego

- zwiększenie przebiegów między naprawami

- poprawa niezawodności pojazdu i warunków pracy maszynisty

- podniesienie mocy lokomotywy nawet o $50 \%$.

Stosowane są nowoczesne, ekonomiczne silniki spalinowe i prądnice czołowych producentów światowych. W celu poprawy estetyki i komfortu pracy gruntownej przebudowie podlegają również kabiny maszynisty.

Pierwszą lokomotywą zmodernizowaną przez PESA zgodnie z tą idea jest SM42 w wersji dwuagregatowej. Dwuagregatowy napęd eliminuje niewspółmiernie 
- the costs of purchasing and repairing the diesel engine are lower as a result of using a typical, mass-produced engine for working machines, but meeting the current railway requirements in the field of exhaust gas emissions

- maintenance costs are reduced as a result of:

- extending the mileage of locomotive for periodic repair

- less wear of engine parts

- lower prices for spare parts

- less oil consumption

- increasing the technical readiness rate

- enabling the quick replacement of container with a damaged or planned sub-assembly to be repaired as a result of modular construction

- increasing the locomotive's tractive force by increasing adhesion as a result of better mass distribution [6].

The activity of Polish producers is not limited to presenting the offers for the delivery of modern vehicles. They submitted the following applications with proposal for implementation of traction vehicles with diesel drive [1] as part of the INNOTABOR Sector Program to the National Center for Research and Development:

- locomotive platform with advanced diesel-electric (multi-system) drive systems

- electric-diesel shunting locomotive with power of approx. $1 \mathrm{MW}$

- modernization of the shunting-line diesel locomotive through the use of a modern gaspowered diesel engine

- light two-section rail bus with a double power unit for transport services in regional traffic.

\subsection{Plans of provincial authorities}

The Polish producers' proposals are usually ahead of the provincial authorities' plans to purchase and modernize the railway vehicles included in their development strategies. Below there are excerpts from some of the strategies related to rolling stock, from which it can be guessed that they may also apply to diesel vehicles:

a) Dolnośląskie Province: " Replacement and modernization of regional, metropolitan, agglomeration rolling stock and local public transport system " [29].

b) Kujawsko-Pomorskie Province: " Undertakings identified so far: The plan of the province is limited to the purchase of modern rolling stock for regional connections on electrified lines " [30].

c) Łódź Province: " Implementation and modernization of the transport system to improve connections between settlement centres " [31].

d) Małopolska Province: " Activities for the development of public transport. Purchase of wysokie zużycie paliwa, co jest typowym problem klasycznych lokomotyw manewrowych.

Zastosowanie dwugregatowości $\mathrm{w}$ modernizowanych lokomotywach przynosi szereg korzyści:

- praca silnika spalinowego o wyższej sprawności powoduje mniejsze zużycie paliwa

- poprawiona jest widoczność z kabiny maszynisty w wyniku obniżenia przedziałów maszynowych przy zabudowie silników spalinowych o mniejszych gabarytach

- mniejsze są koszty zakupu i napraw silnika spalinowego w wyniku zastosowania typowego, produkowanego seryjnie silnika do maszyn roboczych, jednakże spełniającego aktualne wymagania kolejowe w zakresie emisji spalin

- mniejsze są koszty utrzymania w wyniku:

- wydłużenia przebiegu lokomotywy do naprawy okresowej

- mniejszego zużycia części silników

- niższych cen części zamiennych

- mniejszego zużycia oleju

- zwiększenie wskaźnika gotowości technicznej

- umożliwienie szybkiej wymiany kontenera $\mathrm{z}$ uszkodzonym bądź planowanym do naprawy podzespołem w wyniku modułowej konstrukcji

- zwiększenie siły pociagowej lokomotywy przez zwiększenie przyczepności w wyniku lepszego rozłożenia mas [6].

$\mathrm{Z}$ przedstawionych informacji wynika, że zakres modernizacji oferowanych przez producentów jest szerszy niż w realizowanych kontraktach.

Aktywność polskich producentów nie ogranicza się tylko do przedstawiania ofert dostawy nowoczesnych pojazdów. Zgłosili oni do Narodowego Centrum Badań i Rozwoju w ramach Programu Sektorowego INNOTABOR następujące wnioski z propozycją realizacji pojazdów trakcyjnych z napędem spalinowym [1]:

- platforma lokomotyw z zaawansowanymi spalinowo - elektrycznymi (wielosystemowymi) układami napędowymi

- elektryczno - spalinowa lokomotywa manewrowa o mocy ok. 1 MW

- modernizacja lokomotywy spalinowej manewrowo - liniowej poprzez zastosowanie nowoczesnego silnika spalinowego zasilanego gazem

- lekki dwuczłonowy autobus szynowy z podwójnym zespołem napędowym, do realizacji przewozów w ruchu regionalnym.

\subsection{Plany władz wojewódzkich}

Propozycje polskich producentów wyprzedzają z reguły plany władz wojewódzkich co do zakupów i modernizacji pojazdów kolejowych ujętych w ich strategiach rozwoju. Poniżej przytoczone zostały fragmenty niektórych strategii dotyczących taboru kolejowego, z których można tylko domyślać się, że mogą dotyczyć także pojazdów spalinowych: 
rolling stock for servicing the connections within the Province " [28].

e) Mazowieckie Province: " Modernization of railway lines and rolling stock will increase the importance of railway transport in national as well as international communication " [32].

f) Opole Province: The needs of the Opole province have also been diagnosed in the range of rolling stock purchase. Apart from the modernization of main and local railway lines (including the reconstruction of stations, stops and other accompanying infrastructure), the purchase of rolling stock is planned [33]

g) Podkarpackie Province: In the development strategy of this province it is found that investments in modern rolling stock are also necessary [27].

h) Pomorskie Province: In the development plans of province it is found that the developed public transport will be characterized by high quality of provided services (e.g. thanks to improvement of infrastructure and rolling stock [34].

i) Świętokrzyskie Province: "A number of subactivities concerning, among others, modernization and extension of the Świętokrzyskie railway infrastructure and around it, purchase of modern rolling stock, optimization of the network of connections and promotion of railway transport" [35].

j) Wielkopolska Province: " Purchase and revitalisation of rolling stock and extension of the rolling stock maintenance system " [36].

k) Zachodniopomorskie Province: In January 2010, thanks to the funds of the Regional Operational Programme of Zachodniopomorskie Province (ROP - WZ), ten modern rail buses with diesel drive were bought. The bought rolling stock will be used primarily for the regional connection services: Szczecin Goleniów - Kołobrzeg - Koszalin (No. 402); Szczecin - Szczecinek - Chojnice (No. 210); Szczecin - Wałcz - Piła (No. 403) [37].

It is worth to mention that the Polish Chamber of Railway Equipment Producers and Railway Service Providers was planning to organize the XVII Conference "Modernization of rolling stock - purchase and maintenance" on days $3 \div 5$ June 2020 , the organization of which for known reasons will have to be postponed in time [5].

\subsection{Development works on hydrogen supply of trac-} tion vehicles

Problems related to exhaust gas emissions have caused the works on alternative energy sources. An example of such works are analyses concerning the advanced technologies for the use of hydrogen in light suburban vehicles on the non-electrified routes [2]. a) województwo dolnośląskie: "Wymiana i modernizacja taboru regionalnego, metropolitalnego, aglomeracyjnego i lokalnego systemu transportu publicznego" [29].

b) województwo kujawsko - pomorskie: "Dotychczas zidentyfikowane przedsięwzięcia: Plan województwa ogranicza się do zakupu nowoczesnego taboru kolejowego dla połączeń regionalnych na liniach zelektryfikowanych" [30].

c) województwo łódzkie: "Realizacja i modernizacja systemu transportowego $\mathrm{w}$ celu poprawy powiązań między ośrodkami osadniczymi" [31].

d) województwo małopolskie: "Działania na rzecz rozwoju transportu zbiorowego. Zakup taboru kolejowego do obsługi połączeń na terenie województwa" [28].

e) województwo mazowieckie: "Modernizacja linii kolejowych i taboru zwiększy znaczenie transportu kolejowego w komunikacji krajowej, jak też międzynarodowej" [32].

f) województwo opolskie: zdiagnozowane zostały potrzeby województwa opolskiego także w zakresie zakupu taboru kolejowego. Oprócz modernizacji linii kolejowych magistralnych oraz lokalnych (obejmującej między innymi odbudowę dworców, przystanków oraz pozostałej towarzyszącej infrastruktury planuje się zakup taboru kolejowego [33].

g) województwo podkarpackie: w strategii rozwoju tego województwa stwierdza się, że konieczne są również inwestycje w nowoczesny tabor kolejowy [27].

h) województwo pomorskie: w planach rozwoju województwa stwierdzono, że rozwinięty transport zbiorowy będzie cechował się wysoką jakością świadczonych usług (m.in. dzięki poprawie stanu infrastruktury i taboru [34].

i) województwo świętokrzyskie planuje: "Szereg poddziałań, dotyczących m.in. modernizacji i rozbudowy świętokrzyskiej infrastruktury kolejowej i około kolejowej, zakupu nowoczesnego taboru, optymalizacji siatki połączeń oraz promocji transportu kolejowego" [35].

j) województwo wielkopolskie: "Zakup i rewitalizacja taboru kolejowego oraz rozbudowa systemu utrzymania taboru kolejowego" [36].

k) województwo zachodniopomorskie: w styczniu 2010 roku dzięki środkom Regionalnego Programu Operacyjnego Województwa Zachodniopomorskiego (RPO - WZ) zakupionych zostało dziesięć nowoczesnych autobusów szynowych o napędzie spalinowym. Zakupiony tabor kolejowy przeznaczony będzie przede wszystkim do obsługi połączeń regionalnych: Szczecin - Goleniów Kołobrzeg - Koszalin (nr 402); Szczecin Szczecinek - Chojnice (nr 210); Szczecin - Wałcz - Piła (nr 403) [37]. 
The first hydrogen cell-powered vehicle in the world went on track on 16 September 2018 in Bremervörde in Germany, and a day later two trains were included in the passenger service in Lower Saxony. The train called Coradia iLint was built at the Alstom plant in Salzgitter in Germany. It reaches a speed of $140 \mathrm{~km} / \mathrm{h}$, on one refueling it can move all day, and thanks to full autonomy it can travel up to $1000 \mathrm{~km}$. The Polish rolling stock producers have engaged in several projects, the effect of which is to be the production of new and modernization of currently operated vehicles through the use of hydrogen fuel to power the engine [22].

\section{Bibliography / Bibliografia}

[1] Agenda badawcza programu sektorowego INNOTABOR. Innowacyjny tabor szynowy do przewozów pasażerskich, towarowych $i$ specjalnego przeznaczenia. Warszawa 15.07.2016

[2] D'Ovidio G., Carpenito A., Masciovecchio C., Ometto A.: Preliminary analysis on advanced technologies for hydrogen light-rail train application in sub-urban non electrified routes. National Scientific Seminar SIDT. Politecnico Di Bari. 14-15.09.2017. University of L'Aquila ITALY

[3] Electrification of U.S. Railways: Pie in the sky, or realistic goal? https://www.eesi.org/articles/view/eelectrification - of - u.s. - railways - pie - in - the - sky - or - realistic goal

[4] http://mapa.plk - sa.pl/

[5] http://www.modernizacjataboru.pl/xvii - konferencja

[6] http://www.pesa.pl/wp - content/uploads/2018/07/ naprawy_PL.pdf

[7] http://www.usa.xmc.pl/transport - w - usal

[8] https://fpspoznan.pl/

[9] https://pl.wikipedia.org/wiki/Lista_lokomotyw_spalino wych_eksploatowanych_w_Polsce

[10] https://pl.wikipedia.org/wiki/Lista_spalinowych_zespo $\%$ C5\% $82 \% C 3 \%$ B 3w_trakcyjnych_i_wagon\% $\% \overline{3} \%$ B 3 w_eksploatowanych_w_Polsce

[11] https://utk.gov.pl/pl/raporty - $i$ - analizy/analizy - $i$ monitoring/statystyka - przewozow - to/15775,Dane eksploatacyjne - w - 2020 - rMonthly - Statistics 2020.html

[12] https://utk.gov.pl/pl/raporty - $i$ - analizy/analizy - $i$ monitoring/statystyka - przewozow - pa/15767,Dane eksploatacyjne - w - 2020 - rMonthly - statistics 2020.html

[13] https://www.allianz - pro - schiene.de/wp - content/uploads/2020/01/191021_anteil_elektrifizierter_s trecken_im_staatlichen_eisenbahnnetz.pdf

[14] https://www.newag.pl/nasza - oferta/lokomotywy spalinowel

[15] https://www.newag.pl/nasza - oferta/spalinowe - zespoly - trakcyjnel

[16] https://www.newag.pl/newag - s - a - podpisal - kontrakt - na - modernizacje - 20 - lokomotyw - spalinowych - z - pkp - intercity/
Warto wspomnieć, że Polska Izba Producentów Urządzeń i Usług na Rzecz Kolei planowała zorganizować w dniach 3? 5 czerwca 2020 r. XVII Konferencje „Modernizacja taboru szynowego - zakup i utrzymanie", której organizacja $z$ wiadomych powodów będzie musiała być odroczona w czasie [5].

4.4. Prace rozwojowe nad wodorowym zasilaniem pojazdów trakcyjnych

Problemy związane $\mathrm{z}$ emisją spalin spowodowały uruchomienie prac nad alternatywnymi źródłami energii. Przykładem takich prac są analizy dotyczące zaawansowanych technologii dla zastosowania wodoru w lekkich pojazdach podmiejskich na trasach niezelektryfikowanych [2].

Pierwszy na świecie pojazd napędzany ogniwami wodorowymi wyjechał na tory 16 września 2018 roku w Bremervörde w Niemczech, a dzień później dwa składy zostały włączone do obsługi pasażerskiej w Dolnej Saksonii. Pociag o nazwie Coradia iLint zbudowany został w zakładach Alstom w Salzgitter w Niemczech. Osiaga prędkość $140 \mathrm{~km} / \mathrm{h}$, na jednym tankowaniu może poruszać się przez cały dzień, a dzięki pełnej autonomii może pokonać do $1.000 \mathrm{~km}$. Polscy producenci taboru zaangażowali się w kilka projektów, których efektem ma być produkcja nowych i modernizacja obecnie eksploatowanych pojazdów poprzez zastosowanie paliwa wodorowego do zasilania silnika [22].

[17] https://www.newag.pl/skrocenie - terminu - modernizacji - lokomotyw - 311da - dla - pkp - lhs/

[18] https://www.rynek - kolejowy.pl/mobile/spalinowe lokomotywy - u - przewoznikow - pasazerskich - sa bardzo - stare - 93119.html

[19] https://www.tvp.info/43066955/spalinowe - lokomotywy - z - mikroprocesorami - pkp - intercity - modernizuje - tabor

[20] https://www.wnp.pl/budownictwo/pkp - plk - ponad 100 - mln - zl - na - elektryfikacje - linii - kolejowej rzeszow - ocice,317834.html

[21] Jednostkowy raport roczny PKP Cargo S.A. za rok 2019.

https://www.pkpcargo.com/media/956438/jednostko wy - raport - roczny - za - 2019 - rok.pdf

[22] Radomski M.: Pociagi wodorowe na polskich torach? To możliwe już $w 2022$ roku, ale do rozwiazania jest kilka problemów. 12.09.2019. https://fleetguru.eu/pl/biznes/

[23] Raport Roczny Grupy PKP za 2018. Warszawa 1.09.2019

[24] Raport roczny PKP Polskie Linie Kolejowe S.A. za 2018 rok

[25] Rocznik Statystyczny Rzeczypospolitej Polskiej. Warszawa 2019

[26] Strategia Rozwoju Społeczno - Gospodarczego Województwa Warmińsko - Mazurskiego do roku 2020. Olsztyn, 2005

[27] Strategia Rozwoju Województwa - Podkarpackie 2020. Rzeszów, sierpień $2013 r$

[28] Strategia Rozwoju Województwa „Małopolska 2030”. Kraków, 29 sierpnia 2019 r. 
[29] Strategia rozwoju Województwa Dolnoślaskiego 2020. 2013

[30] Strategia rozwoju Województwa Kujawsko - Pomorskiego do roku 2020 - Plan modernizacji 2020+. Toruń, 21 października 2013

[31] Strategia Rozwoju Województwa Łódzkiego na lata 2007 - 2020. Łódź, styczeń 2006

[32] Strategia rozwoju województwa mazowieckiego do 2030 roku. Innowacyjne Mazowsze. Załacznik do Uchwaty nr 158/13 Sejmiku Województwa Mazowieckiego z dnia 28 października 2013 r.

[33] Strategia rozwoju województwa opolskiego. Urzqd Marszatkowski Województwa Opolskiego 2005
[34] Strategia Rozwoju Województwa Pomorskiego 2020

[35] Strategia rozwoju Województwa Świętokrzyskiego do roku 2020. Kielce, lipiec 2013 r.

[36] Strategia rozwoju województwa wielkopolskiego do 2030 roku. Poznań, 27 stycznia 2020 roku

[37] Strategia Rozwoju Województwa Zachodniopomorskiego. Szczecin, czerwiec 2010

[38] Tabor kolejowy przewoźników towarowych - stan obecny $i$ plany do 2023 r. https://utk.gov.pl/pl/ dokumenty-i-formularze/opracowania-urzedutran/14279,Tabor-kolejowy-przewoznikowtowarowych-stan-obecny-i-plany-do-2023-r.html 